\title{
PENGARUH DANA PIHAK KETIGA, MODAL BANK, BUNGA KREDIT, BUNGA SBI DAN KREDIT PERIODE SEBELUMNYA TERHADAP KREDIT YANG DIBERIKAN BANK UMUM
}

\author{
I. N Suarmanayasa \\ Jurusan Manajemen, Universitas Pendidikan Ganesha, Singaraja \\ e-mail: nengah.suarmanayasa@undiksha.ac.id
}

\begin{abstract}
Abstrak
Tujuan penelitian ini adalah untuk menganalisis dan menguji pengaruh dana pihak ketiga, modal bank, bunga kredit modal kerja, bunga SBI dan kredit periode sebelumnya baik secara simultan maupun parsial terhadap jumlah kredit yang diberikan bank umum di Indonesia. Penelitian ini menggunakan data dalam bentuk data triwulanan yang diperoleh dari Badan Pusat Statistik Provinsi Bali. Metode pengumpulan data yang dipergunakan adalah metode dokumentasi, selanjutnya dilakukan analisis data dengan model regresi linear berganda. Adapun hasil penelitian ini adalah 1) dana pihak ketiga, modal bank, bunga kredit modal kerja, bunga SBI dan kredit periode sebelumnya secara simultan berpengaruh signifikan terhadap jumlah kredit yang diberikan; 2) dana pihak ketiga dan jumlah kredit periode sebelumnya secara parsial berpengaruh positif dan signifikan terhadap jumlah kredit yang diberikan, 3) bunga SBI secara parsial berpengaruh negatif dan signifikan terhadap jumlah kredit yang diberikan; 4) Modal bank dan bunga kredit modal kerja tidak berpengaruh terhadap jumlah kredit yang diberikan bank umum di Indonesia.
\end{abstract}

Kata kunci : $\quad$ kredit bank umum, modal bank, bunga kredit.

\begin{abstract}
The purpose of this study was to analyze and test the effect of third party funds, bank capital, working capital loan interest, SBI interest and previous period loans both simultaneously and partially on the amount of credit provided by commercial banks in Indonesia. This study uses data in the form of quarterly data obtained from the Central Statistics Agency of Bali Province. The data collection method used is the documentation method, then the data analysis is performed using multiple linear regression models. The results of this study are 1) third party funds, bank capital, working capital loan interest, SBI interest and previous period loans simultaneously have a significant effect on the number of loans granted; 2) third party funds and previous period credit amounts partially have a positive and significant effect on the amount of credit given, 3) SBI interest has a partially negative and significant effect on the number of loans granted; 4) Bank capital and working capital credit interest does not affect the amount of credit given by commercial banks in Indonesia.
\end{abstract}

Keywords: commercial bank credit, bank capital, credit interest.

\section{Pendahuluan}

Perbankan khususnya bank umum merupakan inti dari sistem keuangan yang sekaligus memiliki berbagai fungsi diantaranya: memberikan kredit/pinjaman kepada sektorsektor perekonomian, untuk kebutuhan pembiayaan serta melancarkan mekanisme sistem pembayaran bagi semua sektor ekonomi, sebagai pemasok kebutuhan uang untuk kegiatan transaksi sehingga mekanisme kegiatan moneter dapat berjalan dengan baik. Karena itu bank memegang peranan yang sangat penting dalam menjaga pertumbuhan ekonomi. Di Indonesia sebagai negara berkembang, sumber utama pembiayaan investasi adalah dari penyaluran kredit perbankan. Mengingat pentingnya peranan perbankan maka bank juga mampu mempengaruhi siklus usaha dalam perekonomian secara keseluruhan.

Pada tahun 1999 terjadi penurunan penyaluran kredit yang besar yaitu mencapai 55,82 persen. Keadaan ini merupakan akibat dari kebijakan penyaluran kredit perbankan yang menjadi sangat selektif karena trauma terhadap kredit macet yang menjadi salah satu sumber kerugian bank selama krisis ekonomi. Ini juga dapat ditafsirkan bahwa sektor riil masih mengalami krisis moneter yang berdampak pada penyaluran kredit oleh perbankan. Mulai tahun 2000-an kegiatan ekonomi makin membaik yang dicerminkan dengan terjadinya pertumbuhan penyaluran kredit perbankan. Tetapi pertumbuhan kredit tersebut masih belum maksimal karena belum bisa menjadi mesin pendorong pertumbuhan ekonomi untuk kembali 
pada level sebelum krisis. Ini berarti bahwa fungsi intermediasi perbankan di Indonesia masih belum pulih.

Jumlah kredit yang disalurkan kepada masyarakat diharapkan selalu meningkat setiap tahunnya, mengingat semakin besar kredit yang disalurkan maka pendapatan perbankan juga akan semakin tinggi, semakin tingginya pendapatan berarti semakin kuat permodalan yang pada akhirnya akan meningkatkan kesehatan industri perbankan. Hal terpenting dari penyaluran kredit adalah untuk membantu usaha nasabah yang memerlukan dana, baik dana investasi maupun dana untuk modal kerja. Dengan dana tersebut, maka pihak debitur akan dapat mengembangkan dan memperluas usahanya. Bagi pemerintah, semakin banyak kredit yang disalurkan oleh pihak perbankan, maka semakin baik, mengingat semakin banyak kredit berarti adanya peningkatan pembangunan di berbagai sektor.

Terdapat banyak faktor yang memmengaruhi keputusan bank untuk menyalurkan kredit kepada masyarakat. Bank umum dalam menyalurkan kreditnya dipengaruhi baik oleh faktor internal bank maupun dipengaruhi oleh faktor eksternal bank. Faktor eksternal yang dimaksud adalah Dana pihak ketiga (DPK) yang terdiri dari tabungan, giro dan deposito berjangka merupakan sumber utama untuk penyaluran kredit perbankan. Dana tersebut diperoleh dari masyarakat yang kelebihan dana. Antara dana pihak ketiga dengan kredit yang diberikan terjadi hubungan positif, artinya jika dana pihak ketiga meningkat hal yang sama juga akan terjadi pada kredit yang diberikan, begitu pula sebaliknya (Wahyu Dwipayana, 2007). Semakin banyak dana yang mampu di himpun dari masyarakat maka akan meningkatkan kemampuan bank untuk menyalurkan kredit ke masyarakat.

Selain dana yang dihimpun dari masyarakat, perbankan juga menggunakan modal bank yang dimiliki untuk menyalurkan kredit ke masyarakat. Modal sebuah bank terdiri atas modal inti dan modal pelengkap. Semakin banyak modal yang dimiliki sebuah bank akan semakin baik, karena hal tersebut akan meningkatkan kemampuan bank untuk menyalurkan kredit ke masyarakat. Pendapatan bunga dari penyaluran kredit akan memmengaruhi jumlah laba, baik deviden dan laba ditahan. Hal ini tentu saja meningkatkan pertumbuhan modal dan akhirnya dapat meningkatkan sumber dana untuk menyalurkan kreditnya.

Naik turunnya penyaluran kredit oleh pihak perbankan dipengaruhi oleh bunga kredit. Bila bunga kredit menurun, maka kredit cenderung mengalami peningkatan, begitu juga sebaliknya. semakin tinggi bank mengenakan suku bunga kredit, minat masyarakat untuk meminjam kredit semakin berkurang, sebab debitur dihadapkan dengan jumlah pembayaran kredit ditambah bunga yang tinggi. Namun sebaliknya, apabila bank menentukan bunga kredit yang rendah maka minat masyarakat dalam meminjam kredit bertambah besar. Masyarakat akan merasa yakin dengan menurunnya bunga kredit akan mampu melunasi pinjamannya di masa yang akan datang.

SBI merupakan salah satu alat kebijakan moneter pasar terbuka yang digunakan untuk mengatur jumlah uang beredar di masyarakat. Jumlah kredit yang disalurkan oleh pihak perbankan juga di pengaruhi oleh $\mathrm{BI}$ rate/ bunga SBI. Bila $\mathrm{BI}$ rate/bunga SBI turun, maka kredit cenderung mengalami peningkatan karena bunga pinjaman akan turun seiring dengan turunnya $\mathrm{BI}$ rate/bunga SBI. Berdasarkan paparan yang disampaikan, maka tulisan ini bertujuan untuk memeroleh temuan yang teruji terkait pengaruh Dana Pihak Ketiga, modal bank, bunga kredit, bunga SBI, dan jumlah kredit periode sebelumnya baik secara simultan maupun secara parsial terhadap jumlah kredit yang diberikan bank umum di Indonesia.

\section{Metode}

Lokasi penelitian adalah di Indonesia. Ruang lingkup penelitian terbatas pada pengaruh variabel dana pihak ketiga, modal bank, bunga kredit, bunga SBI, dan jumlah kredit periode sebelumnya terhadap jumlah kredit yang diberikan bank umum di Indonesia. Data yang digunakan dalam penelitian ini adalah data kuantitatif yakni data yang berbentuk angka-angka seperti data jumlah DPK, modal bank, bunga kredit, bunga SBI, dan jumlah kredit. Jenis data berupa data sekunder yang bersumber dari Badan Pusat Statistik, Laporan triwulanan/tahunan BI. 
Variabel-variabel dalam penelitian ini dibedakan menjadi dua kelompok yaitu, 1) variabel terikat (dependent variabel) yang terdiri atas variabel jumlah kredit yang diberikan; 2) variabel bebas (indefendent variabel) yang terdiri atas variabel DPK, modal bank, bunga kredit, bunga SBI, dan jumlah kredit periode sebelumnya. Adapun definisi operasional dari masing-masing variabel adalah sebagai berikut : 1. Jumlah kredit yang diberikan adalah kredit yang disalurkan untuk penggunaan investasi, modal kerja dan konsumsi pada bank umum di Indonesia, berdasarkan data triwulanan dalam satuan milyar rupiah. 2. Modal bank adalah modal bank umum yang terdiri dari modal disetor, cadangan umum, cadangan tujuan, laba tahun lalu, laba tahun berjalan, dan cadangan umum dikurangi penyertaan, berdasarkan data triwulanan dalam satuan milyar rupiah. 3. Dana Pihak Ketiga (DPK) adalah simpanan pihak ketiga bukan bank yang terdiri dari giro, deposito, dan tabungan pada bank umum berdasarkan data triwulanan dalam satuan milyar rupiah. 4. Bunga kredit adalah harga yang harus dibayar oleh nasabah peminjam kepada bank umum. Bunga kredit yang digunakan pada penelitian ini adalah bunga rata-rata kredit modal kerja (KMK) dari seluruh bank umum dalam persentase berdasarkan data triwulanan. Bunga kredit modal kerja digunakan karena sebagian besar pinjaman dari bank berjangka waktu pendek serta untuk ekspansi usaha mayoritas masyarakat memanfaatkan kredit modal kerja. 5. Bunga SBI adalah adalah suatu instrument moneter yang diterbitkan oleh pemerintah dan umumnya digunakan untuk mengatur jumlah uang beredar berdasarkan data triwulanan dalam satuan persen. Bunga SBI yang dipergunakan dalam penelitian ini adalah suku bunga SBI satu bulan. 6. Kredit periode sebelumnya adalah kredit yang disalurkan untuk penggunaan investasi, modal kerja dan konsumsi pada bank umum di Indonesia, berdasarkan data triwulanan dalam satuan milyar rupiah.

Data yang diperlukan dalam penelitian ini dikumpulkan dengan menggunakan metode dokumentasi yaitu melalui pencatatan berbagai dokumen yang ada pada BI, BPS serta publikasi lainnya termasuk dari internet. Teknik analisis data yang digunakan adalah analisis kuantitatif yaitu analisis regresi linier berganda. Analisis tersebut dapat dihitung dengan alat bantu komputer yaitu SPSS Versi 22.0 For Windows. Model regresi yang dipilih adalah model yang memenuhi kriteria terbaik (gooodness of fit) yaitu model yang memiliki nilai koefisien determinasi yang tertinggi dan tidak mengandung unsur pelanggaran asumsi klasik (multikolinearitas, heteroskedastisitas dan autokorelasi) atau memenuhi kriteria BLUE (Best Linier Unbiased Estimator).

\section{Hasil dan Pembahasan}

Penelitian ini menggunakan model regresi linear berganda. Analisis ini bertujuan untuk mendapatkan hasil taksiran regresi yang terbaik yaitu model yang memiliki nilai koefisien determinasi yang tertinggi dan tidak mengandung unsur pelanggaran asumsi klasik (uji normalitas, multikoliniearitas, heteroskedastisitas dan autokorelasi). Berdasarkan rangkuman hasil analisis data yang terdapat pada Tabel 1.1 maka dapat diperoleh persamaan regresi sebagai berikut :

$\hat{Y}_{t}=-13.664,14+0,239 X_{t 1}+0,032 X_{t 2}-2.081,441 X_{t 3}-2.209,377 X_{t 4}+0.818 Y_{t-1}$

Berikut ini pada Tabel 1 disajikan hasil regresi dengan model regresi linear berganda. 
Tabel 1.

Hasil Penaksiran dengan Model Regresi Linear Berganda

\begin{tabular}{|c|c|c|c|c|}
\hline \multirow{2}{*}{ Variable Bebas } & Koefisien & Standar & \multirow{2}{*}{ t- hitung } & \multirow{2}{*}{ Sig } \\
\hline & Regresi & Error & & \\
\hline Dana Pihak Ketiga $\left(\mathrm{X}_{\mathrm{t} 1}\right)$ & 0,239 & 0,111 & 2,145 & 0,039 \\
\hline Modal Bank $\left(X_{\mathrm{t} 2}\right)$ & 0,032 & 0,126 & 0,251 & 0,803 \\
\hline Bunga SBI $\left(X_{t 3}\right)$ & $-2081,441$ & 1026,556 & $-2,028$ & 0,050 \\
\hline Bunga Kredit $\left(X_{t 4}\right)$ & $-2209,377$ & 2044,648 & $-1,081$ & 0,287 \\
\hline Kredit Sebelumnya $\left(\mathrm{Y}_{\mathrm{t}-1}\right)$ & 0,818 & 0,089 & 9,159 & 0,000 \\
\hline Konstanta & $-13664,14$ & & & \\
\hline R Square $\left(R^{2}\right)$ & 0,996 & & & \\
\hline F-hitung & 1671,699 & & & \\
\hline Sig & 0,000 & & & \\
\hline
\end{tabular}

Jumlah Dana Pihak Ketiga, modal bank, bunga SBI, bunga kredit modal kerja dan jumlah kredit periode sebelumnya secara simultan berpengaruh signifikan terhadap jumlah kredit yang diberikan bank umum di Indonesia. Hasil uji statistik menunjukkan signifikan pada taraf nyata 5 persen yang ditunjukkan dengan nilai signifikansi sebesar 0,000 . Hasil penelitian ini menunjukkan bahwa variabel-variabel yang dimasukkan dalam model secara bersama-sama memberikan pengaruh yang signifikan terhadap jumlah kredit yang diberikan bank umum di Indonesia. Nilai koefisien determinasi $\left(R^{2}\right)$ sebesar 0,996 memiliki makna bahwa 99,6 persen variasi (naik turunnya) jumlah kredit yang diberikan bank umum di Indonesia dijelaskan oleh variasi (naik turunnya) DPK, modal bank, bunga SBI, bunga kredit dan jumlah kredit periode sebelumnya sedangkan sisanya 0,4 persen dijelaskan oleh variabel lain yang tidak dimasukkan dalam model.

\section{Pengaruh dana pihak ketiga terhadap jumlah kredit yang diberikan bank umum}

Dana Pihak Ketiga berpengaruh positif dan signifikan terhadap kredit yang diberikan. Hal tersebut menunjukkan bahwa semakin meningkat Dana Pihak Ketiga secara signifikan akan meningkatkan penyaluran kredit kepada masyarakat, begitu pula sebaliknya semakin menurun jumlah dana pihak ketiga akan menurunkan penyaluran kredit yang diberikan kepada masyarakat. Hasil penelitian ini sesuai dengan penelitian yang dilakukan oleh Wahyu Dwipyana (2007) yang menunjukkan bahwa dana pihak ketiga memmengaruhi penyaluran kredit yang diberikan oleh bank pemerintah di Indonesia dan penelitian yang dilakukan Sukarti (2007) juga menyatakan bahwa dana pihak ketiga mempengaruhi penyaluran kredit pada PT. Bank Pembangunan Daerah Bali.

Hasil ini juga mendukung pendapat yang dikemukan oleh Warjiyo (2005), yang mengatakan bahwa dana yang dihimpun oleh perbankan dari masyarakat akan digunakan untuk pendanaan aktivitas sektor riil melalui penyaluran kredit dan untuk meningkatkan taraf hidup masyarakat banyak seperti yang disebutkan dalam UU No.10 tahun 1998. Hasil ini juga sesuai dengan penelitian sebelumnya yang dilakukan oleh Meydianawathi (2006) dan Harmanta \& Ekananda (2005) yang menunjukkan bahwa peningkatan dana pihak ketiga akan diikuti dengan peningkatan penyaluran volume kredit oleh perbankan.

Dengan bertambahnya jumlah bank, persaingan untuk menarik dana dari masyarakat semakin meningkat. Semua berlomba untuk menarik dana sebanyak-banyaknya dan menyalurkannya kembali kepada masyarakat yang membutuhkan baik untuk tujuan produktif maupun konsumtif. Bagi sebuah bank, dana merupakan darah dan persoalan paling utama, sehingga tanpa dana, bank tidak dapat berfungsi sama sekali. Dana-dana yang dihimpun dari masyarakat dapat mencapai 80 persen - 90 persen dari seluruh dana yang dikelola bank dan kegiatan perkreditan mencapai 70 persen - 80 persen dari kegiatan usaha bank. 
Dari berbagai sumber dana yang berhasil dihimpun oleh bank, kemudian bank menyalurkannya kembali dana tersebut kepada masyarakat secara efektif dan efisien. Dana yang berhasil dihimpun dari masyarakat seharusnya sebagian besar dialokasikan untuk kredit. Karena kegiatan pemberian kredit merupakan rangkaian kegiatan utama suatu bank, dimana pemberian kredit adalah tulang punggung kegiatan perbankan. Dari hasil penelitian ini menunjukkan bahwa pihak perbankan sangat selektif dan hati-hati dalam mengalokasikan dananya untuk kredit. Terbukti dari setiap peningkatan Rp 1 miliar dana pihak ketiga hanya diikuti peningkatan kredit sebesar Rp 239 juta, ini berarti dari tambahan dana Rp 1 miliar akan dialokasikan untuk kredit hanya 23,9 persen saja. Artinya porsi DPK yang dijadikan kredit sangat kecil dan hal ini sangat kontradiktif dengan fungsi inetrmediasi yang semestinya dijalankan oleh perbankan. Keadaan ini merupakan akibat dari kebijakan penyaluran kredit perbankan yang sangat selektif karena trauma terhadap kredit macet yang menjadi salah satu sumber kerugian bank. Keadaan ini juga mengindikasikan bahwa pihak perbankan belum percaya kepada debitur sehingga pihak bank mengalokasikan dananya ke tempat lain yang lebih menguntungkan.

\section{Pengaruh modal bank terhadap jumlah kredit yang diberikan bank umum}

Hasil penelitian ini menunjukkan bahwa modal bank tidak berpengaruh terhadap jumlah kredit yang diberikan bank umum di Indonesia. Hasil penelitian ini berbeda dengan hasil penelitian yang dilakukan Sukarti (2007) yang menyatakan bahwa modal bank berpengaruh positif dan signifikan terhadap jumlah kredit yang disalurkan PT. Bank BPD Bali.

Pengelolaan modal bank sangat penting karena fungsi dan peranan modal sangat strategis, khususnya untuk keamanan sebuah bank (bank safety). Modal bank yang terdiri dari modal inti dan modal pelengkap berfungsi untuk fungsi perlindungan, fungsi operasional dan fungsi pengaturan. Sebagian besar aktiva bank (kredit) dibiayai oleh dana pihak ketiga, sehingga fungsi modal disini adalah memberikan perlindungan kepada pemilik deposito dalam denominasi besar. Dari sisi fungsi ini bank-bank yang memiliki modal yang lebih besar dianggap lebih memberikan perlindungan kepada nasabah deposan.

Pada sebuah bank, pendapatan terbesar adalah pendapatan bunga dari penyaluran kredit. Sehingga hal ini menyebabkan bank berlomba-lomba meningkatkan penyaluran kreditnya. Semakin banyak bank menyalurkan kredit maka semakin banyak pendapatan bunga yang akan diperoleh. Ketika pendapatan yang diterima meningkat nantinya dapat mempengaruhi jumlah laba, baik deviden dan laba ditahan. Hal ini tentu saja meningkatkan pertumbuhan modal dan akhirnya dapat meningkatkan sumber dana untuk menyalurkan kreditnya.

Porsi modal bank sangat kecil pengaruhnya (dianggap tidak ada pengaruh) terhadap jumlah kredit yang disalurkan kepada masyarakat. Disini terjadi kecenderungan kalau permodalan bank dikelola dengan baik hanya semata-mata bertujuan untuk mencapai kondisi yang disyaratkan/ditentukan bank sentral yakni untuk memenuhi ketentuan modal inti minimum.

\section{Pengaruh bunga kredit modal kerja terhadap jumlah kredit yang diberikan bank umum}

Hasil penelitian ini menunjukkan bunga kredit modal kerja tidak berpengaruh terhadap jumlah kredit yang diberikan bank umum di Indonesia. Hasil penelitian ini tidak sejalan dengan pandangan Condro (2007) yang menyatakan bahwa semakin tinggi bank dalam menentukan suku bunga kredit, maka minat masyarakat untuk meminjam kredit semakin berkurang, sebab mereka dihadapkan dengan jumlah pembayaran kredit ditambah bunga yang tinggi. Hal tersebut memberatkan masyarakat yang bersangkutan dalam meminjam kredit dan dalam melunasi kreditnya di masa yang akan datang. Namun sebaliknya, apabila bank mengenakan bunga kredit yang rendah maka minat masyarakat dalam meminjam kredit bertambah besar. Masyarakat akan merasa yakin dengan menurunnya bunga kredit akan mampu melunasi pinjamannya di masa yang akan datang.

Hasil penelitian ini juga tidak sejalan dengan penelitian yang dilakukan oleh Chaikal Nuryakin dan Pery Warjiyo (2006) yang menyatakan bahwa kenaikan bunga kredit akan 
menurunkan jumlah kredit yang diminta sedangkan penurunan bunga kredit akan menaikkan jumlah kredit yang diminta. Begitu pula halnya dengan penelitian yang dilakukan oleh Situmorang (2007) yang menyatakan bahwa ketika bunga kredit turun maka porsi kredit usaha kecil terhadap total kredit perbankan meningkat.

Menurut Miraza (2006), bahwa peran suku bunga untuk mendorong investasi tidak diutamakan. Pendapat yang disampaikan bahwa suku bunga akan mengurangi hasrat melakukan investasi ditampik oleh otoritas moneter. Oleh sebab itu otoritas moneter memilih peran suku bunga untuk menstabilkan nilai tukar rupiah. Ini penting karena hubungan fungsional diantara keduanya yakni antara suku bunga pinjaman dengan nilai tukar rupiah masih berjalan. Itu berarti kekhawatiran akan turunnya hasrat berinvestasi akibat dari suku bunga tinggi adalah tidak realitis. Bukan tidak benar, tetapi tidak sesuai dengan kenyataan yang berjalan. Oleh sebab itu masalah investasi tidak dapat diselesaikan dengan matematis, namun dengan seni dalam berbisnis. Untuk menghitung layaknya suatu investasi, faktor suku bunga hanya dijadikan sebagai tolah ukur, sedangkan hasrat debitur untuk melakukan pinjaman berdasarkan dua pendekatan, yaitu pendekatan nilai sekarang dan tingkat pengembalian modal (rate of returns). Artinya debitur tetap mengajukan permintaan kredit meskipun suku bunga naik, sepanjang obyek yang dibiayai menguntungkan.

Penurunan suku bunga kredit yang terbilang lamban, padahal suku bunga acuan Bank Indonesia (BI rate) sudah turun, dinilai bukan satu-satunya faktor penentu yang menjadi kendala perbankan tidak agresif menurunkan tingkat bunga kreditnya. Ketua Umum Perhimpunan Bank-Bank Umum Nasional (Perbanas) Sigit Pramono (2010) menyebutkan, belum maksimalnya penyaluran kredit perbankan bukan semata-mata belum turunnya bunga kredit. Faktor bunga bukan menjadi penentu untuk penyerapan kredit, tapi juga faktor lainnya seperti masalah listrik, politik dan faktor lainnya yang mempengaruhi sektor riil. $\mathrm{BI}$ rate diturunkan sebesar 275 basis poins (bps). Namun suku bunga kredit perbankan secara ratarata hanya menurun 85 bps. Penurunan $\mathrm{BI}$ rate tidak ampuh turunkan suku bunga kredit

Walaupun bunga kredit diturunkan, lanjutnya, namun sektor riil juga tidak bergerak maka penyerapan kredit juga tidak akan terjadi. Di lain pihak, penyerapan kredit dipengaruhi oleh permintaan pembiayaan proyek, modal kerja perusahaan dan konsumsi masyarakat. Kredit yang sensitif dengan bunga adalah dari sektor konsumsi. Jika bunga kredit turun maka kredit KPR (kredit kepemilikan rumah\}, KKB (kredit kepemilikan kendaraan bermotor) akan meningkat, tetapi untuk kredit modal kerja belum tentu permintaannya naik. Kredit modal kerja sangat dipengaruhi oleh permintaan produk suatu perusahaan tersebut. Walaupun bunga kredit diturunkan berapa pun tetapi permintaan produknya tidak begitu besar maka penyerapan kredit modal kerja juga kecil. Permintaan kredit modal kerja juga dipengaruhi oleh tingkat inflasi, dimana inflasi tinggi akan mendorong perusahaan cenderung menambah persediaan produk karena berharap harga naik dan menyebabkan permintaan kredit juga tumbuh. Sedangkan dalam kondisi inflasi rendah kecenderungan perusahaan menekan persediaan, sehingga permintaan kredit modal kerja juga kecil. Permintaan masyarakat luas terhadap kredit rendah karena tahun 2000-an merupakan tahun penuh kegiatan politik menyebabkan kondisi perekonomian tidak menentu.

\section{Pengaruh bunga SBI terhadap jumlah kredit yang diberikan bank umum}

Hasil penelitian menemukan bahwa bunga SBI berpengaruh negatif dan signifikan terhadap jumlah kredit yang diberikan bank umum. Hubungan negatif antara bunga SBI dengan jumlah kredit yang diberikan sejalan dengan hasil penelitian yang dilakukan Sukarti (2007) yang menyatakan bahwa BI rate memiliki pengaruh negatif dan signifikan terhadap jumlah kredit yang disalurkan PT. Bank BPD Bali. Hasil penelitian ini juga sesuai teori yang menyatakan bahwa makin rendah tingkat bunga, maka pengusaha akan lebih terdorong untuk melakukan investasi, sebab biaya penggunaan dana juga makin kecil (Nopirin, 1984).

Hasil penelitian ini juga sesuai dengan penelitian yang dilakukan bank Indonesia Banjarmasin tentang respon suku bunga dan kredit bank di Kalimantan Selatan terhadap kebijakan moneter (2007), yang menyatakan bahwa transmisi kebijakan moneter efektif dalam mempengaruhi penyaluran kredit di Kalimantan Selatan. Terlihat dari variabel SBI/BI rate dengan lag tiga bulan berpengaruh secara negatif dan signifikan terhadap 
perkembangan kredit. Hal ini didukung oleh fakta bahwa pada saat Bank Indonesia menurunkan tingkat suku bunga $\mathrm{SBI} / \mathrm{BI}$ rate, bank umum akan merespon dengan penurunan tingkat suku bunga kredit yang pada gilirannya akan mendorong peningkatan penyaluran kredit.

Keadaan ekonomi di Indonesia saat ini yang penuh persaingan dan kondisi yang tidak menentu menyebabkan bank-bank umum berlomba-lomba untuk meningkatkan sumber dana bank yang kemudian disalurkan kembali dalam bentuk kredit. Penghasilan bunga dari penyaluran kredit ini merupakan pendapatan utama bank. Dalam prakteknya kebijakan bank Indonesia mengenai tingkat suku bunga SBI menjadi patokan bagi bank umum untuk meningkatkan atau menurunkan tingkat suku bunga kedit. Kebijakan Bank Indonesia ada dua yaitu kebijakan kontraktif meningkatkan tingkat suku bunga SBI dan kebijakan ekspansif menurunkan tingkat suku bunga SBI. Ketika suku bunga SBI meningkat maka bank-bank umum akan meningkatkan suku bunga kredit untuk menyeimbangkan peningkatan dari SBI begitu juga apabila terjadi penurunan.

Kecenderungan tingginya suku bunga SBI akan diikuti oleh naiknya suku bunga simpanan dan secara otomatis akan menaikkan suku bunga pinjaman. Hal ini tentu menjadi kontradiktif dengan fungsi intermediasi. Dengan adanya kenaikan bunga pinjaman tersebut akan berpengaruh terhadap keinginanan pengusaha untuk berinvestasi. Alasannya, seorang pengusaha akan menambah pengeluaran investasi lebih besar dari tingkat bunga yang harus dibayar untuk dana investasi tersebut yang merupakan ongkos untuk penggunaan dana (cost of capital). Pelaku usaha yang merupakan para debitur bank akan terkena imbas dengan adanya kenaikan tingkat suku bunga, karena hal ini akan menaikkan probabilitas gagal bayar (default) dan tentu saja akan menghambat tingkat pertumbuhan kredit di Indonesia.

\section{Pengaruh kredit periode sebelumnya terhadap jumlah kredit yang diberikan bank umum}

Hasil penelitian menemukan bahwa kredit periode sebelumnya berpengaruh positif dan signifikan terhadap jumlah kredit yang diberikan bank umum. Hasil penelitian ini sejalan dengan penelitian yang dilakukan Bank Indonesia Banjarmasin tentang analisis respon suku bunga dan kredit bank di Kalimantan Selatan terhadap kebijakan moneter (2007) yang menyatakan bahwa variabel perkembangan kredit lag satu bulan sebelumnya memiliki pengaruh positif terhadap perkembangan kredit saat ini. Secara teori, dampak perkembangan kredit sebelumnya berpengaruh terhadap perkembangan kredit saat ini, namun tidak dipastikan pengaruhnya harus positif atau negatif.

Pihak bank selalu berusaha untuk meningkatkan jumlah kredit yang disalurkan ke masyarakat. Tiap tahun perencanaan kredit selalu ditetapkan dan dievaluasi agar sesuai dengan kondisi yang ada. Dari berbagai sumber dana yang berhasil dihimpun oleh bank, kemudian bank menyalurkannya kembali dana tersebut kepada masyarakat secara efektif dan efisien. Dana yang berhasil dihimpun dari masyarakat sebagian besar dialokasikan untuk kredit. Karena kegiatan pemberian kredit merupakan rangkaian kegiatan utama suatu bank, dimana pemberian kredit adalah tulang punggung kegiatan perbankan. Bila di perhatikan neraca bank, akan terlihat bahwa sisi aktiva bank akan didominasi oleh besarnya jumlah kredit yang diberikan, sedangkan bila kita perhatikan pula laporan Laba Rugi bank, akan terlihat oleh bahwa sisi pendapatan bank akan didominasi oleh besarnya pendapatan dari bunga dan provisi kredit. Ini dikarenakan aktivitas bank yang terbanyak akan berkaitan erat secara langsung ataupun tidak langsung dengan kegiatan perkreditan.

Hampir semua kegiatan perekonomian masyarakat membutuhkan bank dengan fasilitas kreditnya, dimana melalui pemberian kredit pula akan banyak transaksi pembayaran nasabah melalui rekeningnya sehingga tujuan dari pemberian kredit selain untuk mendapatkan hasil yang optimal dari pemberian kredit tersebut, juga untuk keamanan bank yaitu keamanan untuk nasabah penyimpan sehingga melalui kredit, bank akan menambah dananya dengan sendirinya. Kredit yang aman akan memberikan dampak yang positif bagi bank yaitu kepercayaan masyarakat pada bank akan bertambah. 


\section{Simpulan dan Saran}

Berdasarkan pembahasan yang telah diuraikan maka dapat dibuat simpulan sebagai berikut: 1 . Dana Pihak Ketiga, modal bank, bunga kredit modal kerja, bunga SBI dan jumlah kredit periode sebelumnya secara simultan berpengaruh signifikan terhadap jumlah kredit yang diberikan bank umum di Indonesia. 2. Dana Pihak Ketiga dan jumlah kredit periode sebelumnya secara parsial berpengaruh positif dan signifikan terhadap jumlah kredit yang diberikan, sedangkan bunga SBI secara parsial berpengaruh negatif dan signifikan terhadap jumlah kredit yang diberikan. Modal bank dan bunga kredit modal kerja tidak berpengaruh terhadap jumlah kredit yang diberikan bank umum di Indonesia.

Berdasarkan simpulan yang telah diuraikan, maka dapat diajukan saran sebagai berikut : 1) Pemerintah dan masyarakat diharapkan dapat menggairahkan sektor riil, ketika sektor riil kembali bangkit maka sektor keuangan (bank) juga akan bisa melakasanakan fungsi intermediasi dengan semestinya. Peningkatan permintaan kredit dari sektor riil adalah cerminan adanya peningkatan pembangunan di berbagai sektor. 2) Pihak perbankan hendaknya memberikan kemudahan bagi pengusaha khususnya usaha kecil dan menengah dalam proses perolehan kredit untuk kelangsungan usahanya, tentunya tanpa mengabaikan unsur kehati-hatian.

\section{Daftar Pustaka}

Agenor, P.R., J. Aizenman, dan A. Hoffmaister. 2000. The Credit Crunch in East Asia: What Can Bank Exess Liquid Assets Tell Us? NBER, Inc., Cambridge. Working Paper 7951.

Bank Indonesia. 2007. Analisis Respon Suku Bunga dan Kredit Bank di Kalimantan Selatan Terhadap Kebijakan Moneter. Kajian Ekonomi Regional Kalimantan Selatan : BI Banjarmasin www.google.com

Chaikal Nuryakin dan Perry Warjiyo. 2006. Perilaku Penawaran Kredit Bank di Indonesia, Kasus Pasar Oligopoli Periode Januari 2001 - Juli 2005. Buletin Ekonomi Moneter dan Perbankan. Oktober 2006. www.bi.go.id

Gujarati, Damodar. 1997. Ekonometrika Dasar. Jakarta : Erlangga

Insukindro. 1995. Ekonomi Uang dan Bank. Teori dan Pengalaman di Indonesia. Yogyakarta: BPFE.

Kasmir. 2004. Bank \& Lembaga Keuangan Lainnya, Edisi Keenam. Jakarta : PT Rajagrafindo Persada

Meydianawathi. 2006. "Analisis Pengaruh Indiaktor Perbankan Terhadap Penawaan Kredit Sektor UMKM Pada Bank Umum dan Dampaknya Terhadap PDB Indonesia" (tesis). Denpasar : Universitas Udayana

Muliaman D.Hadad. 2004. Model Estimasi Permintaan dan Penawaran Kredit Konsumsi Rumah Tangga di Indonesia. Direktorat Penelitian dan Pengaturan Perbankan. Bank Indonesia. Jakarta : (www.bi.go.id)

Setyari. 2006. "Analisis Beberapa Variabel yang Mempengaruhi Posisi Fungsi Intermediasi Bank-bank Umum di Indonesia" (tesis). Denpasar : Universitas Udayana

Situmorang, Devi R. 2008. Analisis Faktor-faktor yang Mempengaruhi Permintaan Kredit Perbankan di Sumatera Utara. Artikel : www.google.com

Soedrajad Djiwandono. 2001. Bergulat dengan Krisis dan Pemulihan Ekonomi Indonesia. Jakarta : Pustaka Sinar Harapan 
Sudirman, I Wayan. 2000. Manajemen Perbankan, Suatu Aplikasi. Denpasar : BP

Sugiyono. 2004. Metode Penelitian Bisnis. Bandung : CV Alfabeta

Sukarti. 2007. "Pengaruh Modal, DPK, BI Rate, dan Inflasi Terhadap Kredit yang Disalurkan PT Bank BPD Bali" (tesis). Denpasar : Universitas Udayana

Sukirno, Sadono. 2001. Pengantar Teori Makro Ekonomi Edisi Kedua. Jakarta : PT Raja Grafindo

Undang-undang Republik Indonesia No. 10 Tahun 1998 tentang Perbankan (Perubahan atas Undang-undang No.7 Tahunn 1992)

Wahyu Dwipayana. 2007. "Pengaruh Suku Bunga Kredit, Dana Pihak Ketiga, Tingkat Inflasi dan Kurs terhadap Jumlah Kredit pada Bank Pemerintah di Indonesia 1996-2005" (tesis). Denpasar : Universitas Udayana

Warjiyo, Perry. 2004. Mekanisme Transmisi Kebijakan Moeneter di Indonesia. Jakarta : Pusat Pendidikan dan Studi Kebanksentralan BI. 